\title{
The nutritional value of new varieties of high-yielding triticale: Feeding value of triticale for broiler chickens
}

\author{
A.E. Widodo ${ }^{1,2}$, J.V. Nolan ${ }^{1}$ \& P.A. lji $^{1 \#}$ \\ ${ }^{1}$ School of Environmental and Rural Science, University of New England, \\ Armidale, NSW 2351, Australia \\ ${ }^{2}$ Department of Animal Science, University of Papua, Manokwari - West Papua 98314, Indonesia
}

(Received 8 April 2014; Accepted 21 January 2015; First published online 16 March 2015)

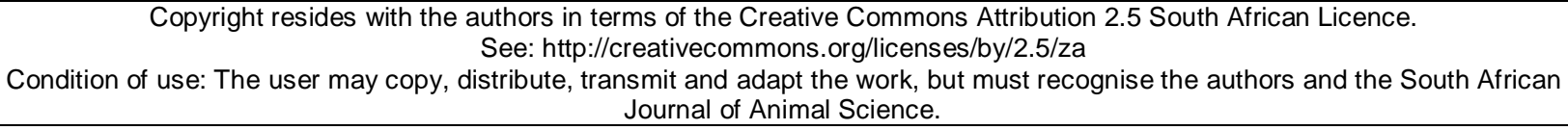

\begin{abstract}
Three hundred and thirty-six day-old male Cobb-500 broiler chickens were randomly allotted to seven dietary treatment groups. Twelve chicks were slaughtered on day 1 to obtain baseline data. There were six replicates of each treatment and eight chicks per replicate. The study reports on the assessment of performance and energy utilization of broiler chicks on diets based on five cultivars of triticale (Bogong, Canobolas, Jackie, Tobruk and Endeavour) compared with maize and wheat, with no supplemental microbial enzymes over a 22-day experimental period. The results showed that diets based on Bogong and maize were superior to the other diets. Birds on all the triticale diets except Canobolas achieved better growth than birds on the wheat-based diet. Birds in the Bogong, Jackie and Tobruk diet groups had higher energy, fat and protein intake; net energy for production (NEp) and energy, fat and protein retention.
\end{abstract}

Keywords: Cultivars, Bogong, Canobolas, Jackie, Tobruk and Endeavour, gross response, energy utilization

\# Corresponding author: piji@une.edu.au

\section{Introduction}

Recently released high-yielding triticale cultivars have been shown to be nutritionally better than the earlier triticale cultivars, which had a nutritional value similar to wheat (McGoverin et al., 2011). Based on ingredient analyses, triticale cultivars seem to have a good balance of essential nutrients such as protein and amino acids and the potential to replace wheat and maize in diets for poultry chickens.

Triticale will become an increasingly useful cereal grain in areas where it can be produced in reasonable amounts. The advantages of triticale include high yield, drought tolerance and disease resistance (Boros, 1999). However, more research is needed to evaluate its nutritive value. The concentrations of nutrients in some of the new high-yielding cultivars are variable and should be documented. In order to justify a recommendation as a replacement for other cereals, the energy value of diets based on triticale should be assessed. Energy supply is the key role of cereals in poultry diets (MacLeod, 2002), and cereal grains are the predominant constituent of most practical diets.

The present study was conducted to investigate the energy utilization of broiler chickens on diets containing certain cultivars of triticale and the effects of these cultivars on productivity, compared with maizeand wheat-based diets.

\section{Materials and Methods}

Based on the results of laboratory analyses and in vitro assays of the triticale cultivars in another trial, as well as the relative availability of cultivars, five cultivars of triticale were identified for the in vivo trial reported in this study. Two cultivars, Bogong and Canobolas, had been tested in the preceding in vitro assays. These cultivars were obtained from Viterra Australia, which has plant breeders' rights to market the seeds. Cultivars Jackie, Tobruk and Endeavour were purchased from a local seed retailer. Semi-purified diets (containing high levels of the test ingredient) were formulated to contain $70 \%-75 \%$ of the five cultivars as well as two similar control diets, which contained maize and wheat instead of triticale. All diets were pelleted and formulated to be isoenergetic and isonitrogenous (13 MJ/kg and $220 \mathrm{~g} \mathrm{CP} / \mathrm{kg} \mathrm{DM}$, respectively) and were offered without microbial enzyme supplementation. The diets were formulated using least-cost 
formulation software Concept, Educational Version 8.01.01 (Agri-data, 2008). The seven dietary treatments with their ingredients and nutrient composition are presented in Table 1.

A total of 348 day-old male Cobb-500 broiler chickens (initial weight, $37.15 \pm 0.90 \mathrm{~g}$ ) from a commercial hatchery (Baiada Poultry Pty Ltd, Tamworth, NSW, Australia) were used in this trial. Three hundred and thirty-six chickens were randomly allotted to the seven dietary treatment groups. There were six replicates of each treatment and eight chicks per replicate. The remaining 12 chickens were used to obtain baseline data on body composition.

The chickens were raised in four brooder decks, each deck with four tiers. Each tier contained four cages, each measuring $60 \times 42 \times 23 \mathrm{~cm}$, and the chickens were kept in groups of three in the same treatment. To balance the distribution by location of cages, only the top three tiers were used. The cages were set up in two climate-controlled rooms (two brooder decks in each room). The diets were pelleted and provided to the birds along with water ad libitum. The temperature was maintained at $35^{\circ} \mathrm{C}$ for the first two days and gradually decreased to approximately $24^{\circ} \mathrm{C}$ by day 22 . On day 18 , three birds from each cage, of approximately the same weight, were transferred to metabolism cages to enable the total collection of excreta for the last four days of the trial period. Prior to transfer, feed intake and body weight were recorded. The rearing conditions for birds moved to the metabolism cages were similar to those remaining in the brooder cages, which were kept to assess feed intake and body weight. A schedule of 18 hours light and 6 hours dark was maintained at both locations.

Table 1 Ingredient and nutrient composition $(\mathrm{g} / \mathrm{kg})$ of each dietary treatment

\begin{tabular}{|c|c|c|c|c|c|c|c|}
\hline \multirow{2}{*}{ Ingredients } & \multicolumn{5}{|c|}{ Triticale cultivars } & \multirow{2}{*}{ Maize } & \multirow{2}{*}{ Wheat } \\
\hline & Bogong & Canobolas & Jackie & Tobruk & Endeavour & & \\
\hline Cereal $^{1}$ & 730.0 & 730.0 & 750.0 & 730.0 & 730.0 & 700.0 & 720.0 \\
\hline Soycomil $P^{2}$ & 201.0 & 193.0 & 179. & 201.0 & 199.0 & 244.0 & 210.0 \\
\hline Sunflower oil & 31.0 & 31.0 & 30.0 & 31.0 & 30.0 & 20.0 & 30.0 \\
\hline Dicalcium phosphate & 7.0 & 8.0 & 6.0 & 5.0 & 4.0 & 9.0 & 5.0 \\
\hline Limestone & 18.0 & 21.0 & 22.0 & 21.0 & 22.0 & 15.0 & 22.0 \\
\hline DL-Methionine & 5.0 & 7.0 & 4.0 & 4.0 & 4.0 & 4.0 & 6.0 \\
\hline Common salt & 5.0 & 7.0 & 6.0 & 5.0 & 8.0 & 5.0 & 4.0 \\
\hline Premix $^{3}$ & 2.0 & 2.0 & 2.0 & 2.0 & 2.0 & 2.0 & 2.0 \\
\hline Choline Cl-70 \% & 1.0 & 1.0 & 1.0 & 1.0 & 1.0 & 1.0 & 1.0 \\
\hline \multicolumn{8}{|c|}{ Calculated nutrient composition $(\mathrm{g} / \mathrm{kg})$} \\
\hline $\mathrm{ME}(\mathrm{MJ} / \mathrm{kg})$ & 13.0 & 13.0 & 13.0 & 13.0 & 13.0 & 13.0 & 13.0 \\
\hline Crude protein & 220.0 & 220.0 & 220.0 & 220.0 & 220.0 & 220.0 & 220.0 \\
\hline Crude fat & 45.0 & 44.0 & 44.0 & 47.0 & 43.0 & 41.0 & 44.0 \\
\hline Crude fibre & 25.0 & 25.0 & 25.0 & 25.0 & 25.0 & 24.0 & 25.0 \\
\hline Lysine & 11.7 & 11.5 & 11.1 & 11.4 & 11.9 & 12.3 & 11.3 \\
\hline Methionine & 4.6 & 4.7.0 & 4.6 & 4.5 & 4.6 & 4.8 & 4.8 \\
\hline Tryptophan & 3.6 & 3.5 & 3.6 & 3.6 & 3.6 & 2.6 & 3.1 \\
\hline Calcium & 9.3 & 10.6 & 11.3 & 10.0 & 10.9 & 9.8 & 10.1 \\
\hline Available phosphorus & 5.4 & 4.7 & 6.1 & 5.0 & 4.9 & 5.5 & 4.5 \\
\hline Sodium & 2.0 & 2.9 & 3.5 & 2.1 & 3.3 & 2.0 & 1.6 \\
\hline Chlorine & 2.1 & 2.3 & 2.2 & 2.2 & 2.1 & 3.0 & 2.9 \\
\hline
\end{tabular}

${ }^{1}$ Each diet contained only the relevant cereal grain indicated.

${ }^{2}$ Soycomil $\mathrm{P}$ (63\% crude protein).

${ }^{3}$ Supplied per $\mathrm{kg}$ of diet: $3.6 \mathrm{mg}$ vitamin A (as all-trans retinol); $0.09 \mathrm{mg}$ cholecalciferol; $44.7 \mathrm{mg}$ vitamin $\mathrm{E}$ (as d- $\alpha-$ tocopherol); $2.0 \mathrm{mg}$ vitamin $\mathrm{K}_{3} ; 2.0 \mathrm{mg}$ thiamine; $6.0 \mathrm{mg}$ riboflavin; $5.0 \mathrm{mg}$ pyridoxine hydrochloride; $0.2 \mathrm{mg}$ vitamin $\mathrm{B}_{12}$; $0.1 \mathrm{mg}$ biotin; $50.1 \mathrm{mg}$ niacin; $12.0 \mathrm{mg}$ D-calcium pantothenate; $2.0 \mathrm{mg}$ folic acid; $80.0 \mathrm{mg} \mathrm{Mn;} 60.0 \mathrm{mg} \mathrm{Fe}, 8.0 \mathrm{mg} \mathrm{Cu}$; $1.0 \mathrm{mg} \mathrm{l;} 0.3 \mathrm{mg} \mathrm{Co} ; 1.0 \mathrm{mg} \mathrm{Mo.}$ 
The combined body weight (BW) and feed intake (FI) of birds in each cage were recorded weekly. Mortality was recorded as it occurred, to allow for corrections to be made to the feed intake. The excreta of the birds in the metabolism cages were collected daily between days 19 and 22 . The excreta were dried at $80^{\circ} \mathrm{C}$ over 24 hours, pooled by cage and ground. Subsamples of excreta and ground feed samples of each dietary treatment were stored to determine gross energy (GE) later.

On day 0 (first day), to provide baseline composition data, 12 birds were weighed and slaughtered by cervical dislocation, without feeding. These birds constituted the first slaughtered group. The samples were stored in a freezer $\left(-20^{\circ} \mathrm{C}\right)$ until the end of the trial and processed with the other samples.

At day 22, after collecting the last day's excreta and weighing the birds, the birds were fasted for about $4 \mathrm{~h}$. Two birds were randomly selected from each cage, weighed and killed by cervical dislocation. The whole birds were put in a plastic bag and stored at $-20^{\circ} \mathrm{C}$ until processing. These birds constituted the second slaughter group.

On the processing day, all 12 whole birds from the first slaughtered group were chopped and blended in a heavy-duty blender. The same procedure was carried out on the birds from the second slaughtered group. Approximately $200 \mathrm{~g}$ of the finely ground carcasses were then freeze-dried. After freeze-drying, samples were ground in a coffee grinder and then with a mortar and pestle to produce finely ground homogenous samples, which were analysed for GE, crude fat and nitrogen (N) contents.

The GE of the diets, excreta and ground carcass samples was determined with a bomb calorimeter (IKA ${ }^{\circledR}$ Werke bomb calorimeter; C 7000, GMBH \& Co., Staufen, Germany). Crude fat was determined using the Soxhlet method and chloroform as a solvent (AOAC, 2000; ID 920.39). The $\mathrm{N}$ content of all samples was determined using a Leco FP-2000 analyser, with ethylenediaminetetraacetate acid (EDTA) as a calibration standard and a multiplication factor of 6.25 was used to derive $\mathrm{CP}$ from total $\mathrm{N}$.

Nutrient accretion and other variables were calculated using the following equations as described by Olukosi et al. (2008) with slight modifications for apparent metabolizable energy (AME), which was calculated from data on total excreta collection.

The AME of the diet and its utilization were calculated using the following formula:

$$
\operatorname{AME}(\mathrm{kJ} / \mathrm{kg})=\frac{(\text { GE diet } \mathrm{x} \text { feed intake }(\mathrm{g}))-(\text { GE excreta } \mathrm{x} \text { excreta weight }(\mathrm{g}))}{(\mathrm{GE} \operatorname{diet} \mathrm{x} \text { feed intake }(\mathrm{g}))}
$$

a) Initial GE of carcass $\left(\mathrm{GE}_{0}\right)(\mathrm{kJ})=$ carcass $\mathrm{GE}(\mathrm{kJ} / \mathrm{g}) \times$ bodyweight of bird day $0(\mathrm{~g})$

b) Final GE content in carcass $\left(\mathrm{GE}_{\mathrm{i}}\right)(\mathrm{kJ})=$ carcass $\mathrm{GE}(\mathrm{kJ} / \mathrm{g}) \times$ bodyweight of bird day $22(\mathrm{~g})$

c) Net energy for production (NEp) $(k J)=\left(G_{i}\right)-\left(G_{0}\right)$;

d) $\quad \mathrm{HP}$ (heat production) (kJ) = MEI-NEp;

e) where MEI is ME intake, which was calculated from the following equation:

f) $\quad \mathrm{MEl}(\mathrm{kJ})=\mathrm{ME}(\mathrm{kJ} / \mathrm{g}) \times$ feed intake $(\mathrm{g})$;

g) Energy retained as fat $\left(R E_{f}\right)(k J)=$ carcass fat $(g) \times 38.2 \mathrm{~kJ} / \mathrm{g}$;

h) Energy retained as protein $(\mathrm{REp})(\mathrm{kJ})=$ carcass $\mathrm{CP}$ content $(\mathrm{g}) \times 23.6 \mathrm{~kJ} / \mathrm{g}$;

i) The values 38.2 and $23.6 \mathrm{~kJ} / \mathrm{g}$ are energy values per $\mathrm{g}$ of fat and protein, respectively (Larbier \& Leclercq, 1992),

j) Efficiency of ME use for energy retention $\left(K_{R E}\right)=N E p / M E I$;

k) Efficiency of $M E$ use for lipid retention $\left(K_{R E f}\right)=R_{f} / M E l$;

I) Efficiency of ME use for protein retention $\left(K_{R E P}\right)=R E p / M E I$

The experimental protocol was approved by the University of New England Animal Ethics Committee (Approval No AEC09/099). The data were analysed using a one-way ANOVA of Minitab ${ }^{\circledR}$ Version 16 (Minitab, 2010), using diets as the factor. The significance of difference between mean values was determined by Fisher's least significant difference (LSD) test.

\section{Results}

Feed intake did not differ $(P>0.05)$ between the groups over the first week of feeding the diets. However, BW and feed conversion ratio (FCR) of the birds fed on the five diets containing triticale cultivars and the diet containing maize were significantly higher $(P<0.01)$ than for those for the wheat diet (Table 2$)$. At 14 days old, significant differences $(P<0.01)$ were observed in all parameters measured among the dietary treatments. Birds fed triticale and maize diets had eaten more, were heavier and had better FCR than those on the wheat diet. Among the triticale diets, birds given Bogong, Jackie and Tobruk-based diets had higher $(P<0.05) \mathrm{FI}$ and BW than birds offered the Canobolas diet. However, the birds all had similar FCR. FI to 21 days old and BW at day 21 of the birds receiving Bogong, Jackie, Tobruk and Endeavour and maize were higher $(P<0.05)$ than for birds fed the diets containing wheat and Canobolas cultivar, whereas there were no differences $(P>0.05)$ in FCR between the treatments. 
Table 2 Gross responses of broiler chicken given diets based on triticale cultivars up to 7, 14 and 21 days old $^{1}$

\begin{tabular}{|c|c|c|c|c|c|c|c|c|}
\hline & \multicolumn{5}{|c|}{ Triticale cultivars } & \multirow{2}{*}{ Maize } & \multirow{2}{*}{ Wheat } & \multirow{2}{*}{$\mathrm{SEM}^{2}$} \\
\hline & Bogong & Canobolas & Jackie & Tobruk & Endeavour & & & \\
\hline \multicolumn{9}{|l|}{$1-7 d$} \\
\hline FI (g/bird) & 117.0 & 108.0 & 106.0 & 109.0 & 111.0 & 105.0 & 105.0 & 1.8 \\
\hline BW (g/bird) & $123.0^{\mathrm{a}}$ & $115.0^{\mathrm{a}}$ & $117.0^{\mathrm{a}}$ & $118.0^{\mathrm{a}}$ & $117.0^{\mathrm{a}}$ & $123.0^{\mathrm{a}}$ & $101.0^{\mathrm{b}}$ & $1.6^{\star \star}$ \\
\hline FCR $(g / g)$ & $1.38^{\mathrm{b}}$ & $1.40^{\mathrm{b}}$ & $1.38^{\mathrm{b}}$ & $1.36^{\mathrm{b}}$ & $1.37^{\mathrm{b}}$ & $1.22^{\mathrm{b}}$ & $1.66^{\mathrm{a}}$ & $0.029^{\star \star}$ \\
\hline \multicolumn{9}{|l|}{$1-14 d$} \\
\hline FI (g/bird) & $401.0^{\mathrm{a}}$ & $330.0^{d}$ & $386.0^{\mathrm{b}}$ & $373.0^{\mathrm{ab}}$ & $362.0^{\mathrm{ab}}$ & $357.0^{\mathrm{bc}}$ & $313.0^{\mathrm{d}}$ & $5.7^{\star \star}$ \\
\hline BW (g/bird) & $338.0^{\mathrm{a}}$ & $284.0^{\mathrm{b}}$ & $327.0^{\mathrm{a}}$ & $316.0^{\mathrm{a}}$ & $320.0^{\mathrm{ab}}$ & $320.0^{\mathrm{a}}$ & $244.0^{c}$ & $6.1^{\star \star}$ \\
\hline FCR $(g / g)$ & $1.33^{\mathrm{b}}$ & $1.34^{\mathrm{b}}$ & $1.33^{\mathrm{b}}$ & $1.34^{\mathrm{b}}$ & $1.31^{\mathrm{b}}$ & $1.27^{\mathrm{b}}$ & $1.53^{\mathrm{a}}$ & $0.021^{*}$ \\
\hline \multicolumn{9}{|l|}{$1-21 d$} \\
\hline FI (g/bird) & $777.0^{\mathrm{a}}$ & $571.0^{\mathrm{cd}}$ & $712.0^{\mathrm{a}}$ & $662.0^{\mathrm{bc}}$ & $696.0^{\mathrm{ab}}$ & $656.0^{\mathrm{bc}}$ & $503.0^{d}$ & $1.87^{\star \star}$ \\
\hline BW (g/bird) & $690.0^{\mathrm{a}}$ & $547.0^{\mathrm{bc}}$ & $677.0^{\mathrm{a}}$ & $642.0^{\mathrm{a}}$ & $681.0^{\mathrm{a}}$ & $624.0^{\mathrm{ab}}$ & $462.0^{c}$ & $1.67^{\star \star}$ \\
\hline FCR $(g / g)$ & 1.19 & 1.13 & 1.11 & 1.11 & 1.08 & 1.12 & 1.19 & 0.016 \\
\hline
\end{tabular}

The ME content of diets and intake of ME, GE, fat and protein by birds are presented in Table 3 . The ME content differed between diets $(P<0.001)$, from $11.4 \mathrm{MJ} / \mathrm{kg}$ DM for the diet containing Endeavour to 13.3 $\mathrm{MJ} / \mathrm{kg} \mathrm{DM}$ for the diet containing wheat. Among the diets containing triticale, the ME of the Bogong and Tobruk-based diets was higher $(P<0.001)$ than Canobolas, Jackie and Endeavour. In addition, the birds on Canobolas- and Jackie-based diets consumed higher ME $(P<0.001)$ than those containing Endeavour. The ME intake of birds on these diets was not related to their ME content. The birds on the wheat-based diet, which had the highest ME content, had the lowest $(P<0.001)$ ME intake, similar to that for the Canobolas diet, whereas the birds offered the diets with Bogong, Jackie and Tobruk had the highest $(P<0.001) \mathrm{ME}$ intake. The results were similar for GE, fat and protein intake, which were higher $(P<0.001)$ on four of the five diets containing triticale and that containing maize than on the diet containing wheat.

Table 3 Metabolizable energy (ME) of diets (MJ/kg) and intake of ME (MJ), gross energy (GE, MJ), fat $(\mathrm{g})$ and protein ( $\mathrm{g}$ ) per bird on from hatch to $22 \mathrm{~d}$ (DM basis) ${ }^{1}$

\begin{tabular}{|c|c|c|c|c|c|c|c|c|}
\hline & \multicolumn{5}{|c|}{ Triticale cultivars } & \multirow{2}{*}{ Maize } & \multirow{2}{*}{ Wheat } & \multirow{2}{*}{$\mathrm{SEM}^{2}$} \\
\hline & Bogong & Canobolas & Jackie & Tobruk & Endeavour & & & \\
\hline ME & $13.0^{\mathrm{a}}$ & $12.3^{\mathrm{bc}}$ & $12.1^{\mathrm{c}}$ & $12.9^{\mathrm{a}}$ & $11.4^{\mathrm{d}}$ & $12.8^{\mathrm{ab}}$ & $13.3^{\mathrm{a}}$ & $0.12^{\star \star \star}$ \\
\hline ME intake & $13.6^{\mathrm{a}}$ & $9.5^{\mathrm{d}}$ & $12.1^{\mathrm{ab}}$ & $12.0^{\mathrm{ab}}$ & $10.2^{\mathrm{cd}}$ & $11.8^{\mathrm{bc}}$ & $9.4^{\mathrm{d}}$ & $0.31^{\star \star *}$ \\
\hline GE Intake & $17.9^{\mathrm{a}}$ & $12.9^{c}$ & $16.8^{\mathrm{ab}}$ & $15.8^{\mathrm{b}}$ & $15.1^{\mathrm{b}}$ & $15.3^{b}$ & $12.1^{\mathrm{c}}$ & $0.39^{\star \star \star}$ \\
\hline Fat intake & $47.1^{\mathrm{a}}$ & $34.7^{\mathrm{cd}}$ & $43.4^{\mathrm{ab}}$ & $43.6^{\mathrm{a}}$ & $38.3^{\mathrm{bc}}$ & $37.9^{c}$ & $31.5^{\mathrm{d}}$ & $1.05^{\star \star \star}$ \\
\hline Protein Intake & $231.4^{\mathrm{a}}$ & $169.7^{\mathrm{cd}}$ & $219.0^{\mathrm{ab}}$ & $203.9^{b}$ & $196.7^{\mathrm{bc}}$ & $202.7^{b}$ & $156.0^{d}$ & $5.04^{\star \star *}$ \\
\hline
\end{tabular}

Figure 1 shows the influence of the experimental diets on the NEp and HP of the broiler chickens from hatch to day 22. The NEp consumed by the birds fed on the diet containing Bogong, Jackie, Tobruk and 
maize was the same, and was higher $(P<0.01)$ than the NEp consumed by the birds on the Canobolas, Endeavour and wheat diets. Birds fed on the diets containing Jackie, Tobruk, Endeavour, maize and wheat had similar HP values, while the birds on the Bogong-based diet were similar to the birds on maize-based diet but higher $(P<0.05)$ than all other treatments.
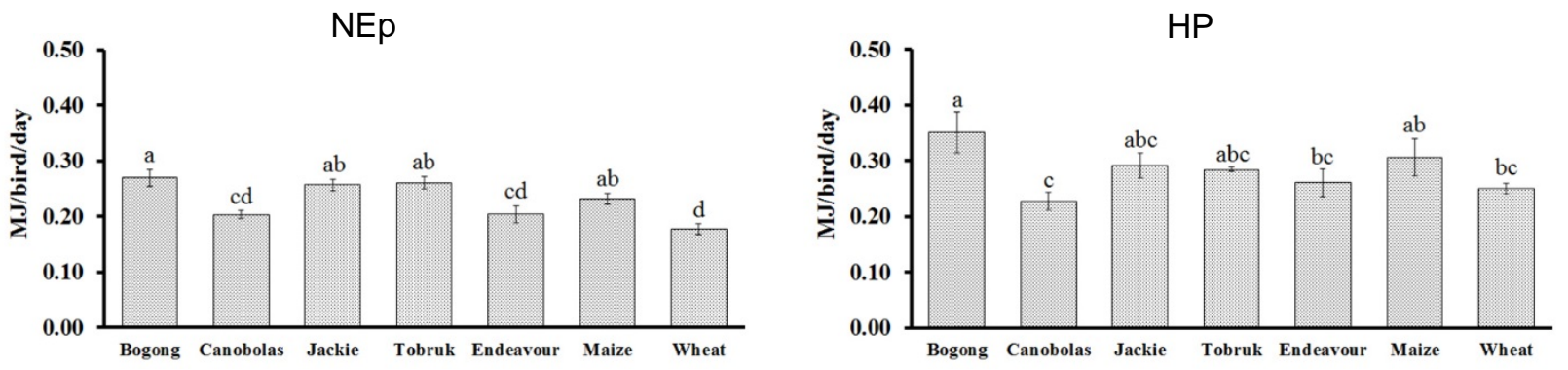

Figure 1 Net energy of production (NEp) and heat production (HP) (MJ/bird/day) of birds on diets based on different triticale cultivars between hatch and 22 days old.

The whole body energy, fat and protein contents at 22 days old are shown in Table 4. The energy content of the carcasses ranged from 3.9 to $5.9 \mathrm{MJ}$ per bird on day 22. The energy content of carcasses of birds fed the Bogong diet was similar to those on Jackie and Tobruk, but higher $(P<0.001)$ than for all other treatments. A similar trend could be seen in the fat and protein contents of the carcass, with the fat content of the birds on the Bogong diet being similar to Jackie and Tobruk. The protein content of the birds on Bogong, Jackie, Tobruk and maize were similar, but higher $(P<0.001)$ than Canobolas, Endeavour and wheat diets.

Table 4 Whole body energy (MJ), fat $(\mathrm{g})$ and protein $(\mathrm{g})$ contents (DM basis) ${ }^{1}$ per bird on 22 days old

\begin{tabular}{|c|c|c|c|c|c|c|c|c|}
\hline & \multicolumn{5}{|c|}{ Triticale cultivars } & \multirow{2}{*}{ Maize } & \multirow{2}{*}{ Wheat } & \multirow{2}{*}{$\mathrm{SEM}^{2}$} \\
\hline & Bogong & Canobolas & Jackie & Tobruk & Endeavour & & & \\
\hline Energy & $5.9^{\mathrm{a}}$ & $4.5^{\mathrm{cd}}$ & $5.6^{\mathrm{ab}}$ & $5.7^{\mathrm{ab}}$ & $4.5^{\mathrm{cd}}$ & $5.1^{\mathrm{bc}}$ & $3.9^{d}$ & $0.14^{\star \star \star}$ \\
\hline Fat & $72.7^{a}$ & $52.0^{\mathrm{bc}}$ & $68.7^{\mathrm{a}}$ & $72.2^{\mathrm{a}}$ & $47.2^{\mathrm{bc}}$ & $57.7^{\mathrm{b}}$ & $42.7^{\mathrm{C}}$ & $2.19^{\star \star \star}$ \\
\hline Protein & $131.2^{\mathrm{a}}$ & $104.0^{c d}$ & $124.7^{\mathrm{ab}}$ & $121.9^{\mathrm{ab}}$ & $111.8^{\mathrm{bc}}$ & $120.3^{\mathrm{ab}}$ & $93.5^{d}$ & $2.57^{\star \star \star}$ \\
\hline
\end{tabular}

${ }^{1}$ Each value represents the mean of six replicates.

${ }^{2}$ SEM: standard error of mean.

${ }^{\text {a-d }}$ Values with unlike superscripts within a row are significantly different at ${ }^{* \star} P<0.001$.

Table 5 shows the influence of the various diets on the rates of deposition of energy, fat and protein from hatch up to day 22 of the experimental period. The daily rate of deposition of energy varied from 0.18 to $0.27 \mathrm{MJ} /$ day, while fat and protein deposition ranged from 1.9 to $3.3 \mathrm{~g} /$ day and 4.3 to $6.0 \mathrm{~g} /$ day, respectively. These were significantly affected $(P<0.001)$ by diet.

The birds on the Bogong, Jackie and Tobruk diet had higher $(P<0.001)$ rates of energy and fat deposition than birds on the other diets. Meanwhile, the rate of protein deposition of the birds on the Bogong, Jackie, Tobruk and maize diets was higher $(P<0.001)$ than that of birds on Canobolas, Endeavour and wheat diets. In addition, the birds on the wheat diets were the lowest in all parameters, namely rate of deposition of energy, fat and protein.

The results of energy retention as fat $\left(R E_{f}\right)$ and protein $(R E p)$ are shown in Figure 2. Energy retention as fat ranged from 0.07 to $0.13 \mathrm{MJ} /$ bird/day, and as protein from 0.10 to $0.14 \mathrm{MJ} / \mathrm{bird} / \mathrm{day}$. The energy retentions as fat in the birds on the Jackie and Tobruk diets were similar to those on the Bogong diet, but higher $(P<0.001)$ than for the Canobolas and Endeavour diets, as well as the maize- and wheat-based diets. Similar to energy retention as fat, the birds in the Bogong, Jackie and Tobruk groups had higher $(P<0.001)$ retention of energy as protein than other groups. The birds provided with the wheat diet had the lowest energy retention as fat and protein, but this was not statistically different from the Canobolas group. 
Table 5 Rate of deposition of energy $(\mathrm{MJ})$, fat $(\mathrm{g})$ and protein $(\mathrm{g})$ per day in broiler chicks grown to 22 days old on diets based on triticale cultivars, maize or wheat ${ }^{1}$

\begin{tabular}{|c|c|c|c|c|c|c|c|c|}
\hline & \multicolumn{5}{|c|}{ Triticale cultivars } & \multirow{2}{*}{ Maize } & \multirow{2}{*}{ Wheat } & \multirow{2}{*}{ SEM $^{2}$} \\
\hline & Bogong & Canobolas & Jackie & Tobruk & Endeavour & & & \\
\hline Energy & $0.27^{\mathrm{a}}$ & $0.20^{\mathrm{cd}}$ & $0.26^{\mathrm{ab}}$ & $0.26^{\mathrm{ab}}$ & $0.20^{\mathrm{cd}}$ & $0.23^{\mathrm{bc}}$ & $0.18^{d}$ & $0.01^{\star \star *}$ \\
\hline Fat & $3.3^{\mathrm{a}}$ & $2.4^{b c}$ & $3.1^{\mathrm{a}}$ & $3.3^{\mathrm{a}}$ & $2.1^{\mathrm{bc}}$ & $2.6^{\mathrm{b}}$ & $1.9^{\mathrm{C}}$ & $0.10^{\star \star \star}$ \\
\hline Protein & $6.0^{\mathrm{a}}$ & $4.7^{\mathrm{cd}}$ & $5.7^{\mathrm{ab}}$ & $5.5^{\mathrm{ab}}$ & $5.1^{\mathrm{bc}}$ & $5.5^{a b}$ & $4.3^{d}$ & $0.12^{\star \star \star}$ \\
\hline
\end{tabular}

${ }^{1}$ Each value represents the mean of six replicates.

${ }^{2}$ SEM $=$ standard error of mean.

${ }^{\text {a-d }}$ Values with unlike superscripts within a row are significantly different at $P<0.001$.
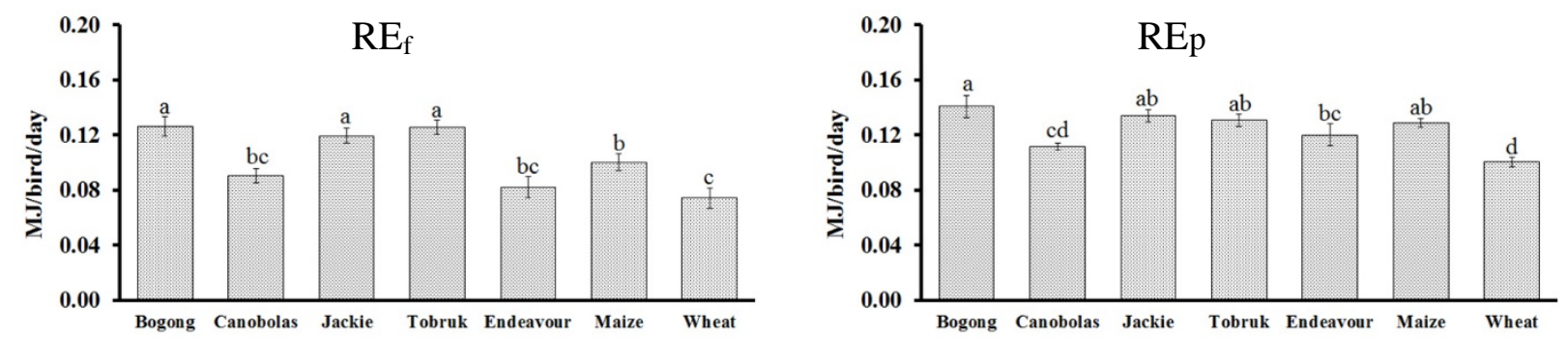

Figure 2 Energy retention as fat $\left(R E_{f}\right)$ and protein $(R E p)(M J / b i r d / d a y)$.

Figure 3 shows the efficiency of utilization of $M E$ for energy retention $\left(K_{R E}\right)$, fat $\left(K_{R E f}\right)$ and protein $\left(K_{R E p}\right)$, respectively. The efficiency of utilization of $M E$ for energy retention $\left(K_{R E}\right)$ and efficiency of utilization of ME for protein retention (K $\left.\mathrm{K}_{\mathrm{REP}}\right)$ of the birds receiving different diets were not different $(P>0.05)$. However, the efficiency of utilization of ME for lipid retention $\left(\mathrm{K}_{\mathrm{REf}}\right)$ was different $(P<0.05)$ between diets. The $\mathrm{K}_{\mathrm{RE}}, \mathrm{K}_{\mathrm{REf}}$ and $\mathrm{K}_{\mathrm{REp}}$ varied from 0.41 to $0.44,0.17$ to 0.22 , and 0.23 to 0.26 , respectively. The birds on the Tobruk diet were the most efficient $(P<0.05)$ in using the ME for fat retention, whereas the birds receiving the diets based on Endeavour, maize, and wheat were less efficient in the use of ME for fat retention.
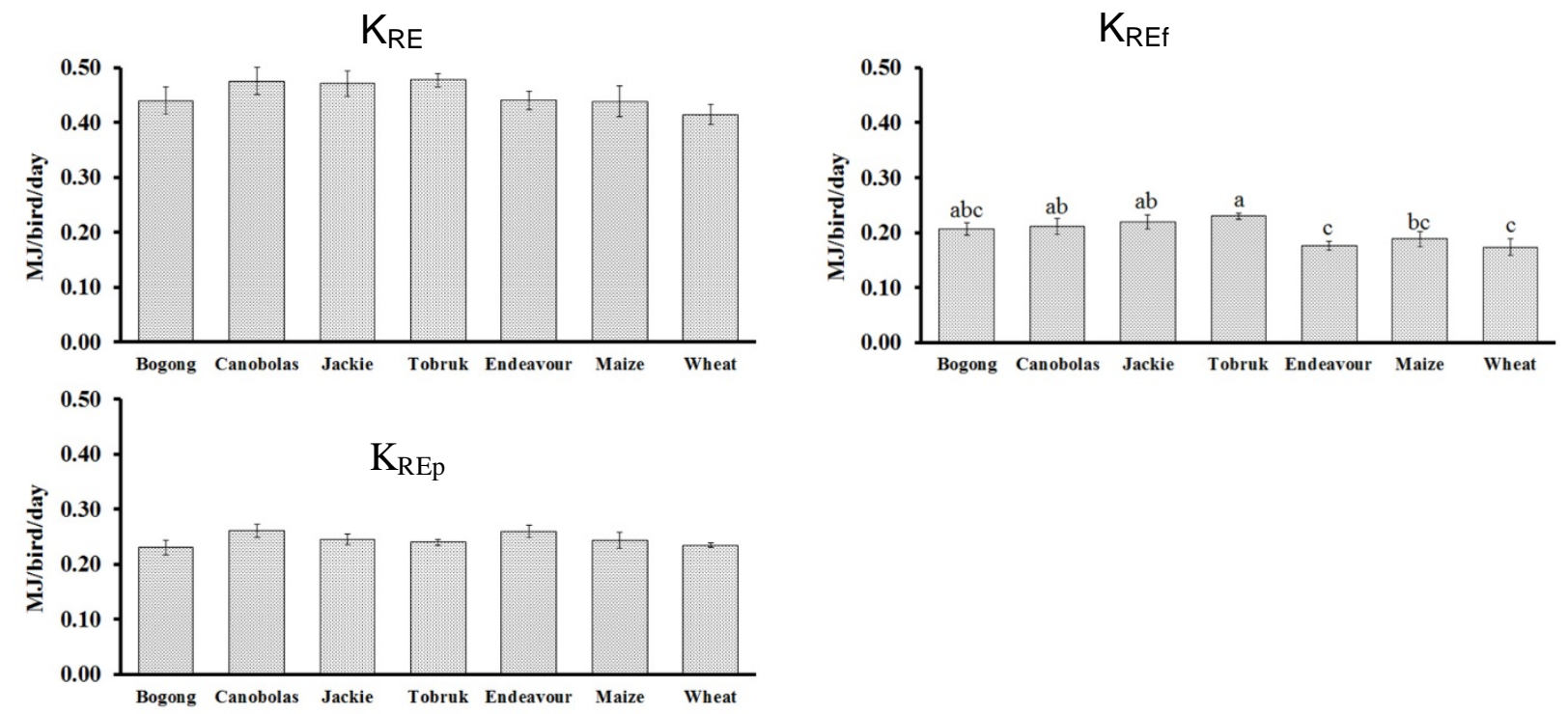

Figure 3 Efficiency of ME utilization for energy retention ( $\left.\mathrm{K}_{\mathrm{RE}}\right)$, fat $\left(\mathrm{K}_{\mathrm{REf}}\right)$ and protein $\left(\mathrm{K}_{\mathrm{REp}}\right)$. 


\section{Discussion}

In the present study, the gross responses expressed as FI, BW and FCR were affected by the dietary treatments. Up to 21 days, mortality rate was less than $4 \%$ and occurred only in the first week of the experimental period. This is possibly owing to the birds adjusting to the diets and other rearing conditions. Body weight was lower than the Cobb breeder specification (Cobb-Vantress Standard). For example, the highest BW to day 21 was about $8 \%$ less than the breeder standard. The lower value may be owing to low starting weight, which was about $15 \%$ less than the guide. The diets were fed without microbial enzyme supplements and the lack of such supplementation was most obvious in the performance of birds on the wheat-based diet.

The feed intake of the birds up to day 7 did not differ between diets. However, feed intake from 0 to 14 days and 0 to 21 days differed significantly between diets. That there was no difference in feed intake between groups up to day 7 may be the result of the birds' dependence on their residual yolk sac. This is in agreement with Turro et al. (1994) and Malik et al. (2011), who suggested that the residual yolk sac supplies certain nutrients to the newly hatched chicken, especially in the first four days post hatch. The demand for dietary nutrients would increase as the yolk became depleted, and dietary effects would become more obvious. The results in the present study showed that triticale cultivars contain more net energy and nutrients than wheat. Furthermore, the heavier BW of chicks on the diets containing triticale was possibly owing to triticale diets being more digestible than the wheat-based diets (Flores et al., 1994).

Metabolizable energy is the standard measure of describing energy requirements for poultry and is widely used in measuring energy contribution from diets under commercial conditions (Lopez \& Leeson, 2008). Metabolizable energy can be determined accurately from the difference between the GE of the feed and the GE of the excreta resulting from a feed (NRC, 1994). In the current study, except for the birds fed Endeavour, the ME content of the other triticale-, maize- and wheat-based diets was between 12 and 13 $\mathrm{MJ} / \mathrm{kg}$. Metabolizable energy intake was lower in birds fed Canobolas and wheat-based diets than the other triticale cultivars and maize-based diets. The lower ME intake of the birds may be a result of the high fibre content and anti-nutritive factors present in Canobolas and wheat, although these were not measured in the current study. Barteczko et al. (2009) reported that the soluble NSP fraction has a negative relationship with AME, owing mainly to an increase in the digesta viscosity. Choct \& Annison (1992), in a study on the antinutritive activity of isolated wheat pentosans, also reported a significant dose-dependent depression in AME. Although the previous laboratory analysis of the triticale cultivars showed a similarity in nutrient contents among the triticale cultivars in this trial, the differences in energy, fat and protein deposition may be because of the differences in digestibility between the triticale cultivars. However, predictions of digestibility from proximate composition may not be as accurate as values obtained from actual feeding trials.

The NEp was measured in this study to determine how useful the various grains were as energy sources, and was found to be significantly different among the treatments. The higher NEp in Bogong, Jackie and Tobruk diets compared with the NEp of the wheat diet indicates the superiority of the three cultivars in terms of nutritive quality. However, HP was substantially higher for diets containing these three cultivars. Olukosi et al. (2008) reported high HP when microbial enzymes were included in the diet. The preferential deposition of energy as protein may elevate HP because more ATP is required to deposit protein than to deposit fat. The carcasses of birds fed diets with Bogong, Jackie and Tobruk showed higher energy retention as fat and protein than the carcasses of birds fed on the maize and wheat diets. It would be expected that more lean tissue was being accumulated in the carcass of chickens that retained more net energy as protein. However, in general, the higher retention of protein than fat in broiler chickens up to 22 days old is probably because at this age broiler chickens are in the fast-growing phase and have not reached the phase at which fat deposition becomes significant (Sanz et al., 2000; Bregendahl et al., 2002). As BW increases, the quantities of body fat and protein increase at different rates, generally tending towards an increase in fat deposition (Leenstra, 1986; Emmans, 1995).

In the present study, the efficiencies of retention of ME, lipid and protein were higher than in that of Olukosi et al. (2008). This may be the result of the difference in ME intake. However, the efficiencies of ME utilization for energy and protein were unaffected by dietary differences. In terms of efficiency of utilization of ME for fat deposition, all the birds fed triticale diets had higher values, and were as efficient as those on maize, but more efficient than birds on wheat. The high level of fat deposition is related to a high ME intake. This is in agreement with Yuan et al. (2008), who reported that consumption of a high-energy diet by broiler chickens increases fat accumulation in the muscle. Similarly an increase in the energy : protein ratio in the diet may stimulate a higher deposition of fat (Wiseman \& Lewis, 1998). The higher fat deposition of the birds fed on Bogong, Jackie and Tobruk diets might be the result of higher digestibility of energy, and possibly other nutrients, but this was not assessed in the current study. 


\section{Conclusion}

The present study showed that broiler chickens fed on certain triticale cultivars (Bogong, Jackie and Tobruk) performed better than birds on wheat-based diets. Birds in the Bogong, Jackie and Tobruk diet groups had higher energy, fat and protein intakes; NEp; energy, fat and protein retention than the birds in the other diets, while the efficiency of utilization of ME for energy and protein by the birds was unaffected. These findings should be tested under practical diets conditions, including supplementation with microbial enzymes.

\section{Acknowledgements} grain.

AB Vista (Marlborough, UK) funded this study. Viterra Australia provided the Bogong and Canobolas

\section{References}

Agri-data, 2008. Creative Formulation Concepts, LLC. Educational version (Concept4ED). http://uww.agridata.com/education.php.

Barteczko, J., Augustyn, R., Lasek, O. \& Smulikowska, S., 2009. Chemical composition and nutritional value of different wheat cultivars for broiler chickens. J. Anim. Feed Sci. 18, 124-131.

Boros, D., 1999. Influence of R genome on the nutritional value of triticale for broiler chicks. Anim. Feed Sci. Techn. 76, 219-226.

Bregendahl, K., Sell, J. \& Zimmerman, D., 2002. Effect of low-protein diets on growth performance and body composition of broiler chicks. Poult. Sci. 81, 1156-1167.

Choct, M. \& Annison, G., 1992. Anti-nutritive effect of wheat pentosans in broiler chickens: Roles of viscosity and gut microflora. Br. Poult. Sci. 33, 821-834.

Emmans, G.C., 1995. Problems in modelling the growth of poultry. Wrld Poult. Sci. J. 51, 77-89.

Flores, M.P., Castañon, J.I.R. \& McNab, J.M., 1994. Nutritive value of triticale fed to cockerels and chicks, Br. Poult. Sci. 35, 527-536.

Larbier, M. \& Leclercq, B., 1992. Energy metabolism. In: Nutrition and Feeding of Poultry. Ed: Wiseman, J., Nottingham University Press, Nottingham. pp. 47-73.

Leenstra, F.R., 1986. Effect of age, sex, genotype and environment on fat deposition in broiler chickens. Wrld Poult. Sci. J. 42, 12-25.

Lopez, G. \& Leeson, S., 2008. Review: Energy partitioning in broiler chickens. Can. J. Anim. Sci. 88, 205-212.

MacLeod, M.G., 2002. Energy utilization: measurement and prediction. In: Poultry Feedstuffs: Supply, Composition and Nutritive Value. Eds: McNab, J.M. \& Boorman, K.N., Vol. 26. pp. 191-217.

McGoverin, C.M., Snyders, F., Muller M., Botes, W.C., Fox, G.P. \& Manley, M., 2011. A review of triticale uses and the effect of growth environment on grain quality. J. Sci. Food Agric. 91, 1155-1165.

Malik, H.E.E., Ali, O.H.A., Elhadi, H.M. \& Elzubeir, E.A., 2011. Residual yolk utilization in fast and slowgrowing chicks, subjected to feed and water deprivation. Asian J. Bio. Sci. 4, 90-95.

Minitab, 2010. Minitab 16 Statistical Software. Minitab Inc. State College. PA.

NRC, 1994. National Research Council; Nutrient Requirements of Poultry: Ninth Revised Edition. The National Academic Press, Washington, USA. pp. 176.

Olukosi, O.A., Cowieson, A.J. \& Adeola, O., 2008. Energy utilization and growth performance of broilers receiving diets supplemented with enzymes containing carbohydrase or phytase activity individually or in combination. Br. J. Nutr. 99, 682-690.

Sanz, M., Lopez-Bote, C.J., Menoyo, D. \& Bautista, J.M., 2000. Abdominal fat deposition and fatty acid synthesis are lower and $\beta$-oxidation is higher in broiler chickens fed diets containing unsaturated rather than saturated fat. J. Nutr. 130, 3034-3037.

Todorov, N.A., 1988. Cereals, pulses and oilseeds. Livest. Prod. Sci. 19, 47-95.

Turro, I., Dunnington, E.A., Nitsan, Z., Picard, M. \& Siegel, P.B., 1994. Effect of yolk sac removal at hatch on growth and feeding behavior in lines of chickens differing in body weight. Growth Dev. Aging 58, 105-112.

Wiseman, J. \& Lewis, C.E., 1998. Influence of dietary energy and nutrient concentration on the growth of body weight and of carcass components of broiler chickens. J. Agr. Sci. 131, 361-371.

Yuan, L., Lin, H., Jiang, K.J., Jiao, H.C. \& Song, Z.G., 2008. Corticosterone administration and high-energy feed results in enhanced fat accumulation and insulin resistance in broiler chickens. Br. Poult. Sci. 49, 487-495. 